\title{
Teacher Perspectives on CLIL Implementation: A Within-Group Comparison of Key Variables
}

\author{
María Dolores Milla Lara \\ Antonio Vicente Casas Pedrosa \\ University of Jaén
}

Received: 27 May 2017 / Accepted: 3 October 2017

ISSN: $1697-7467$

\begin{abstract}
This article reports on the outcomes of a qualitative study carried out with teachers in four eastern Andalusian provinces (Granada, Almería, Jaén, and Córdoba) into their perspectives on the implementation of CLIL programmes. Data triangulation, methodological triangulation, and location triangulation have all been employed to obtain a comprehensive and representative picture into the way in which CLIL programmes are playing out in this context. After framing the topic against the backdrop of the projects, the paper expounds on the objectives, methodology, variables, and procedure employed in the study. The bulk of the article is devoted to outlining its main findings in relation to the ten main fields of interest which have been canvassed: L2 use in class, L2 development: discursive functions, competence development, methodology, materials and resources, evaluation, teacher training and motivation, mobility, coordination, organization, workload, and overall appraisal of bilingual programmes. Within-group comparisons are also carried out to determine the existence of statistically significant differences within the cohort of teachers in terms of a series of identification variables. A detailed diagnosis of where we currently stand in this process of adaptation to CLIL models is provided and the main lacunae to be addressed in this area are pinpointed.
\end{abstract}

Keywords: CLIL, implementation, teacher perspectives, qualitative study, variables

Perspectivas del profesorado sobre la implementación del AICLE: Comparación intragrupal de variables clave

RESUMEN: Este artículo presenta los resultados de un estudio cualitativo realizado con profesorado de las cuatro provincias orientales andaluzas (Granada, Almería, Jaén y Córdoba) para conocer sus perspectivas sobre la implementación de los programas AICLE. Para obtener una imagen representativa y completa del modo en el que dichos programas se están desarrollando en ese ámbito, se ha empleado triangulación de datos, metodología y lugar. Tras situar el tema en el contexto de los proyectos, el artículo explica los objetivos, metodología, variables y procedimiento del estudio. El resto del artículo expone los principales hallazgos en las diez áreas de interés consideradas: uso de la lengua extranjera en clase, desarrollo de la misma (funciones discursivas), desarrollo de competencias, metodología, materiales y recursos, evaluación, formación del profesorado y motivación, movilidad, coordinación, organización, carga de trabajo y valoración general de los programas bilingües. También se han realizado comparaciones intragrupales para determinar la existencia de di- 
ferencias estadísticamente significativas dentro del profesorado en función de una serie de variables de identificación. Se proporciona un diagnóstico detallado de la situación actual en el proceso de adaptación a los modelos de AICLE y se explican las principales lagunas que han de afrontarse.

Palabras clave: AICLE, implementación, perspectivas del profesorado, estudio cualitativo, variables

\section{INTRODUCTION}

Our increasingly globalised and interconnected world requires individuals who are capable of communicating with each other. Being multilingual is, in the zeitgeist of the present society, no longer a desirable asset for the job market and intercultural relations: it has progressively turned into a necessary skill which is taken for granted. In the European Union, this is particularly relevant given that the free market and the free movement of workers from one country to another are taking place in a multicultural and multilingual continent. As the European Commission (henceforth, EC) (1995: 47) puts it, multilingualism is "part and parcel of both European identity/citizenship and the learning society". For that reason, European Policies are aimed at promoting the learning of at least two foreign languages, what is often called the "Mother Tongue +2 " principle (European Commission, 1995: 47). Furthermore, the EC policies have the aim of developing citizens' useful competence in a language, that is, "to use it for a purpose, so that the language becomes a tool rather than an end in itself" (European Commission, 2005: 5).

European member states, therefore, are doing their best to implement these language policies in their curricula (Marsh, 2002; Lorenzo, Casal and Moore, 2009; Pérez Cañado, 2012), which has involved substantial investment for the accomplishment of these objectives (Pérez Cañado, 2016b). Nevertheless, the "delivery gap" (Marsh, 2002: 9) that exists between the objectives and the results obtained has forced European nations to look for alternative methods of language learning and teaching that maximise language learning within the existing educational structures, and it is within this context that Content and Language Integrated Learning comes to the fore as a "European solution to a European need" (Marsh, 2002: 11). Stemming from Bilingual Education in the United States, Canadian immersion programmes, and International Schools in Europe, CLIL has been "championed across Europe" (Pérez Cañado, 2012: 330). In fact, Eurydice (2006) shows that virtually every country in Europe is adopting CLIL, and adapting it to fit their context, giving rise to a wide variety of CLIL practices. In Deller's words (2005: 29), CLIL is "spreading fast and here to stay".

The "explosion of interest" (Coyle, 2006:2) that CLIL has originated has, in turn, given rise to a considerable number of studies that analyse what this concept entails in practice and its effectivity to raise language learning standards. CLIL, which originated in 1994, has recently reached its watershed, given the "applicability of 10-15 year project cycles in education" (Marsh, 2012: 197). Therefore, this is the perfect timing to carry out a comprehensive stocktaking of CLIL's inner workings in order to evaluate its Strengths, Weaknesses, Opportunities, and Threats and contribute to its development, making the necessary adjustments for the future. It is to these aims that the present study contributes. This paper reports on the findings of a qualitative study carried out in the four eastern provinces (Almería, Córdoba, 
Granada, and Jaén) of the southern-most region in Spain, Andalusia. The study gathered teachers' insights on the implementation of the Andalusian Plurilingualism Promotion Plan (Plan de Fomento del Plurilingüismo en Andalucia, Junta de Andalucía, 2005; henceforth APPP), a CLIL programme launched in 2005 by the Andalusian educational authorities which has had a great uptake since its beginnings and which continues to foster plurilingualism amongst Primary and Secondary school students year after year all over the region.

The APPP was put forward as a part of a strategic move to modernize Andalusia through the development of the students' mother tongue as well as of their linguistic and cultural competences in a FL. This change of mentality from a monolingual mindset to a plurilingual one has posed some difficulties, especially given that the Andalusian levels of competence in an L2 are lower than the Spanish average, which is in turn lower than the European average (Ministerio de Educación, Cultura y Deporte, 2012).

Despite this fact, the Andalusian educational authorities did not desist from their pursuit to increase the population's linguistic competence, and the region has been referred to as "a monolingual community striving to jump on the bilingual bandwagon" (Pérez Cañado, 2011: 392). As a consequence, the number of schools that adhere to the network of bilingual schools does not cease to increase year after year: from an initial number of 915 public schools that were registered in the programme in the academic year 2014-2015 (Europa Press, 2014), a "swift uptake" (Lancaster, 2016: 149) has taken place, and 1,337 public bilingual schools are currently enrolled in the programme. Andalusia has therefore become the Spanish community with the highest number of bilingual schools in Spain (Junta de Andalucía, 2017), and the educational authorities intend to reach 1,500 bilingual schools in the region by 2020 (Europa Press, 2017).

The PEDLA (Plan Estratégico de Desarrollo de las Lenguas en Andalucia, Strategic Plan for the Development of Languages in Andalusia) was launched in 2017 to consolidate the achievements of the APPP, as well as to adapt the objectives established by the APPP to the current reality of Andalusia. Its broad objectives, therefore, are in line with those of the APPP, and they consist of increasing the students' communicative competence, improving their level of proficiency in a FL, upgrading language teaching methodologies, and increasing the number of teachers participating in the programme with a $\mathrm{C} 1$ level in a FL.

After framing the topic against an updated review of the literature and the main findings obtained so far in this area, this paper reports on the objectives and methodology (research design, sample, variables, instruments, and data analysis) of this study. These will be followed by a comprehensive account of the findings obtained, divided into the ten aspects that have been canvassed: L2 use in class, L2 development: discursive functions, competence development, methodology, materials and resources, evaluation, teacher training and motivation, mobility, coordination and organization, workload, and overall assessment of bilingual programmes. Data, location and methodological triangulation are employed, which allow us to obtain a clear and representative view of the way CLIL unfolds in this context. In addition, within-group comparisons are also carried out. These are fundamental in order to determine the existence of any statistically significant differences within the cohort of teachers in terms of a series of identification variables. With the results obtained, it will be possible to determine where we stand in terms of CLIL implementation in the area and what the main lacunae are in order to keep pushing the CLIL agenda forward in our community. 


\section{Prior Research}

Numerous studies have been dedicated to examining the inner workings of the APPP at a grassroots level from its beginnings in order to find the areas that need improvement as well as the positive aspects of this plan. Attention will be paid here to those studies which have focused on teacher training and teachers' judgments on the way the APPP is developing.

The first large study on the APPP was the one coordinated by Lorenzo (Pablo de Olavide University in Seville), and carried out between 2006 and 2007. It consisted of a quantitative and qualitative study on the outcomes of CLIL instruction, with outstandingly positive results. Several publications sprang forth from this study: Casal and Moore (2008), which described the research design; Lorenzo, Casal and Moore (2009), which analysed the qualitative outcomes; and Lorenzo, Casal, Moore and Afonso (2009), which explained the quantitative data from the study. Given that this study was the first of its type in Andalusia, it constitutes "a necessary starting and reference point in the research panorama of our autonomous community" (Pérez Cañado, 2011 : 393).

Also in the Andalusian context, Rubio Mostacero's (2009) study (University of Portsmouth and University of Jaén), carried out in the province of Jaén in June 2005, examined NLA (Non-Linguistic Area) teachers' training needs by carrying out interviews to 20 teachers in 4 secondary schools. Her aim was to design a training course for NLA teachers. In order to do so, she first proposed a model and then revised it after analysing the results she obtained from her needs analysis study. A final revision was made after it was reviewed by the interviewees and a local Teacher Training Centre (TTC) (Pérez Cañado, 2011). The novelty of this study accounted for its intuitive nature (Pérez Cañado, 2011). However, the study would have benefitted from methodological and data triangulation and a larger and more geographically representative sample. Furthermore, the interviewees were not involved with the APPP implementation, which would have been desirable for a study of these characteristics (Pérez Cañado, 2011).

A few years later, Cabezas Cabello (University of Málaga) conducted a study (2010) between January and June 2009 in which over 100 teachers and 30 coordinators all across Andalusia were interviewed in order to develop a SWOT (Strengths, Weaknesses, Opportunities, Threats) analysis of the APPP. He also intended to explore the possible discrepancies between the top-down and bottom-up approaches to the APPP. The interviews were conducted in 30 Primary and Secondary schools which implemented a CLIL approach in English, French or German. This study, which presented several methodological shortcomings (e.g. lack of data and methodological triangulation, as well as unclear research design), was the first of its kind in our area.

Cabezas Cabello's conclusions were, however, devastating concerning the development of the plan and the integration of top-down and bottom-up approaches. In his own words (2010: 90), "The APPP document is full of wishful thinking and false expectations; as some teachers put it, "in the present circumstances of most Andalusian schools, it is neither viable nor doable"".

Another qualitative study, in this case in the province of Jaén, was conducted by Gálvez Gómez (2013). She carried out a SWOT analysis of the APPP in José Plata, a Primary school in Mengíbar (Jaén), in order to evaluate stakeholders' perspectives concerning the plan and to compare the cohorts. She carried out survey research, by means of questionnaires delivered to 89 students, 64 parents, and 3 teachers. The analysis of the data was both qualitative and 
quantitative, and data triangulation was ensured to reduce possible bias. It was found that the stakeholders were generally satisfied with the programme, with the student group being the most enthusiastic of the three. While students were especially optimistic concerning their use of the L2, the development of English in class and the methodology — which they claimed increased their motivation towards learning English-, teachers and parents were most satisfied with evaluation, teacher training and mobility (2013). It must be noted, however, that students provided mixed responses concerning their competences in oral expression and understanding the FL (2013), that the workload on the part of the teachers increased and insufficient teacher-training was provided and that parents were concerned about the price of the materials, the need for more information about the programme, and not being able to help their children with their homework.

A more comprehensive study was conducted by Lancaster (2016), focused on Secondary education. She carried out a study in eight high schools in the province of Jaén, in order to compare the perspectives of two different stakeholders concerning the APPP implementation, using for this aim the results obtained by two different group-administered questionnaires delivered to 53 teachers and 692 students between the ages of 12 and 17 (from first year of Compulsory Secondary Education to first year of Non-Compulsory Secondary Education). The stakeholders were questioned about students' use, competence and development of English in class; methodology; materials and resources and ICT $^{1}$; evaluation; teachers' use, competence and development of English in class (students); teacher training (teachers); mobility; and, finally, improvement and motivation towards English (students); and coordination and organisation (teachers).

The results were analysed using both quantitative and qualitative methods. It emerged that, while both teachers and students had positive attitudes concerning the APPP, it was the teacher cohort that provided more positive feedback (even though students' enthusiasm was evident, especially concerning their development and use of the L2 and the methodology employed in class). Teachers were most satisfied concerning materials, resources and ICT, evaluation, teacher training and mobility. Both cohorts agreed on accepting the methodology that comes with using a CLIL approach in class. Altogether, the global results of the study suggested that "the APPP has been extensively welcomed into our education system" (Lancaster, 2012:154). The sample for this study was considerable. However, only 8 public bilingual schools were involved in the data collection, and they were all selected within a restricted location. Furthermore, the study was conducted at a given point in time and there was no longitudinal evaluation of the results. In addition, there is a lack of methodological and data triangulation, since the study only focused on the cohort of teachers (versus students and parents) and there were no data-collection tools other than questionnaires.

The specific issue of teacher training for CLIL has also aroused attention. In a study conducted by Pérez Cañado (2016b) on this issue, it came to light that the two most crucial aspects in teacher training that needed to be addressed were the proficiency of the teachers in the L2 and training in the "theoretical underpinnings of CLIL" (2016b: 269), as well as practical aspects of CLIL such as "student-centered methodologies" (2016b: 269), despite the fact that, for those who are not experts in the matter, stepping up the language skills of teachers is all that is required (Fortanez-Gómez, 2013). The lack of appropriate training

\footnotetext{
${ }^{1}$ Information and Communication Technology.
} 
programmes for teachers and of institutional support were also voiced as a concern by CLIL teachers (Pérez Cañado, 2013). These findings mirror those of previous articles such as Blanca Pérez (2009), García Mayo (2009; in Pérez Cañado, 2016b), and Lasagabaster and Ruiz de Zarobe (2010b). According to the author (2016b: 268), this cornerstone "must be covered prior to turning to other lacunae". As far as the language deficiencies on the part of the teachers were concerned, it was an aspect that created unease among the researchers (Bruton, 2013; Pérez Cañado, 2013; and Pérez Cañado and Ráez Padilla, 2015) and the teachers, since it affected both NLA teachers and FL teachers (Pérez Cañado, 2016b). ${ }^{2}$ Moreover, it was suggested that, instead of NLA teachers instructing students via the FL, it was language teachers who should be trained to impart specialised content lessons (Bowler, 2007).

The figure of the teaching assistant was more specifically scrutinised by Sánchez Torres (2014). He carried out a qualitative longitudinal analysis aimed at gathering information concerning the role of the language assistant in Andalusia and the relationships between the assistant and the APPP language coordinator. For this study, methodological and data triangulation were employed, and the gathering of data consisted of interviews and observation of multiple informants (15 language assistants, 15 coordinators in bilingual schools in the province of Seville, and five other people, including the representatives from teacher training schools, the regional bilingual coordinator, and the director of international educational programmes). It was found that, for teachers and language assistants, working back to back influenced them at a personal and professional level: they experienced changes in motivation, in the pedagogy used in their lessons, and in communication, all these aspects affecting their overall evaluation of the APPP experience. It was also found that the language assistants, on average, fulfil most of their expected functions. However, in terms of didactics, cultural approaches, and leisure activities, their performance should be stepped up.

Interestingly, these findings are in line with a previous study by Tobin and Abello-Contesse (2013), in which seven teaching assistants were interviewed for eight months. In this study, it was found that there were difficulties in combining culture and interaction in class when there was a second teacher. Instead, the language assistant was used as a "human CD" (2013: 224), or a "cultural tour guide" (2013: 224), rather than making the most of this potential to push students' Intercultural Communicative Competence (ICC). Sánchez Torres (2014) also found that there was both cooperation and collaboration between the assistant and the language teacher, and that this relationship was fruitful with regard to participation, communication in the classroom, and contextualisation of the lessons. In contrast with some studies (Navés, 2009; Rubio Mostacero, 2009; Cabezas Cabello, 2010; Lancaster, 2012; Pérez Cañado, 2012; Gálvez Gómez, 2013; Lancaster, 2016), teacher training was not considered a major drawback for the development of the programme, since it did not emerge as a cause for concern. Nevertheless, it was agreed that the language assistant was a figure that needed more pedagogical and methodological training, and that teachers should improve the use they make of such a resource.

In addition, some successful practices were identified in schools where students' communicative competences in the L2 had improved. The most outstanding of all was the elaboration of an integrated curriculum, but other relevant factors were related to the teaching staff: for example, pursuing both content and language objectives at the same time, the level

\footnotetext{
${ }^{2}$ In Andalusia, a study found that teachers who were involved in the CLIL programme had a low level of English, not exceeding a B2 CEFRL level in English (Lorenzo, Casal, and Moore, 2009).
} 
of competence in the L2 of B2 or higher, the teachers' interest in participating in innovative proposals, and the level of collaboration between the content and the language teachers. In contrast, the main flaws detected were a limited degree of consecution of language objectives (which were rather commonly reduced to learning a list of lexical items), a high level of difficulty of the materials employed in class, a neglect of oral skills (paired with a lack of scaffolding to conduct certain tasks), and last, but not least, a poor variety of discourses under study, with narration being given most attention, in detriment of real communicative situations such as debates or discussions.

The above-mentioned issues of teacher training were also explored by De la Maya Retamar \& Luengo González (2015). They identified some key areas in which teacher training was insufficient in the education degree. First of all, the time dedicated to the study of the foreign language (henceforth, FL) was scarce, when compared against a FL Degree. Furthermore, didactic training in the L2 was necessary, for there was a complete lack of it in some cases. Second, training was required on basic theoretical aspects of CLIL and development of bilingual programmes. Third, there was no coherence between the training received in class and the "real" classroom in terms of languages that were taught. Last but not least, graduates were not appropriately informed of the functioning of bilingual programmes, which posed difficulties for their successful incorporation into these programmes.

Finally, focusing on competences, García Sánchez and Rodríguez Collado (2015) conducted a study aimed at evaluating whether a competence-based education model was being followed by some schools participating in the APPP, and the effects of following such methodology. Therefore, they interviewed teachers from the bilingual sections, bilingual coordinators and a language assistant from six secondary schools in the province of Almería ( 9 people in total), and conducted qualitative and quantitative analyses of the data recorded. They concluded that following a competence-based model or not doing so depended on certain factors, such as the subject under study (whether or not it was an NLA class), the teachers' background (veteran teachers tended to follow a more traditional approach), or the degree of implementation of the school's Integrated Curriculum. Furthermore, they reached some remarkable conclusions in relation to the bilingual programme itself.

To sum up, several deficiencies have come to light in previous research, which have the potential of damaging the correct execution of the APPP. These deficiencies are to be faced immediately, for they not only affect the teachers themselves but also have an effect on the students and the curriculum in general, too. Therefore, actions should be taken to ensure correct training, appropriate materials, coordination among teachers, and access to mobility. These, amongst other factors, would allow teachers to work to their full potential for a better implementation of bilingualism in our community. This is precisely the niche which the present study seeks to fill since it is aimed at conducting an empirically sound investigation that supersedes the lacunae of prior studies into the topic.

\section{Clil in andalusia: from the appp to the pedla}

For the APPP and the PEDLA to develop satisfactorily and come to fruition, the teaching body undoubtedly constitutes a key element. While several studies (Marsh, 2000; Coyle, 2006; Merisuo-Storm, 2007; Seikkula-Leino, 2007; Lorenzo, Casal \& Moore, 2009; 
Lasagabaster, 2011; García Sánchez \& Rodríguez Collado, 2015; Heras \& Lasagabaster, 2015; Lancaster, 2015, 2016) showed that following a CLIL methodology in class has positive effects on students, it was also proposed that teachers who are engaged in CLIL are more motivated than non-CLIL teachers (Llinares \& Dafouz, 2010; Dallinger et al., 2016), given that CLIL implies making a special extra effort when it comes to lesson planning and materials development (Fortanet-Gómez, 2013; Vinke, 1995). In Bruton's words (2013:589), "nobody will deny that CLIL is hard work for teachers".

First of all, it was suggested that following a CLIL methodology not only demanded more of the student, but also of the teacher. The integration of content and language demanded a mind-shift on the part of the teacher, which, according to Pérez Cañado (2013:15) "points to the very hallmark of CLIL". Where NLA non-CLIL teachers focused only on the content of their subject, CLIL implied an overall change of methodology. CLIL teachers needed to be aware of other factors, such as their code-switching strategies (Gierlinger, 2015), or the ways in which the disciplinary discourse will be introduced to the students (Fortanet-Gómez, 2013). Nevertheless, this could be seen in a positive light, since this implied a higher cognitive engagement on the part of the teacher (Pavón \& Ellison, 2013) and a fulfilment of some of the demands of teachers' mindsets, such as access to technologies, mobility, and global communication (Pérez Vidal, 2013).

Secondly, CLIL required a revisiting of teacher roles both in class and in the wider institutional context. Teachers and teaching assistants now coordinated with each other following the institution's Integrated Language Curriculum in order to jointly achieve the language objectives previously planned. This promoted Project-Based Learning and Cooperative Learning, which were, in turn, transferred into the way the lessons were delivered. In fact, it was suggested that CLIL favoured a more participative, student-centred, and authentic learning (Lorenzo, 2007; Pavón \& Ellison, 2013; Pérez Cañado, 2016a; Pérez Cañado, in press).

Both strong and weak forms of CLIL were identified depending on the weight that language and content had in the curriculum. In strong versions, CLIL programmes "lean more on content-based instruction" (Pavón \& Ellison, 2013:69), whereas in weak versions, it was the language teacher the one who brought content to the language class. Depending on where programmes stood in this CLIL continuum, Massler, Stotz, and Queisser (2014) drew a distinction between Type A CLIL programmes, in which the focus was on content instruction in the FL, and Type B programmes, with content-based language lessons. They also identified Type $\mathrm{C}$ programmes, with integration of content and language as a subject on its own, but they acknowledged the rare frequency with which they occurred. Having an NLA teacher provide linguistic support for students could potentially make the language teacher feel threatened. However, it was vital to keep in mind that, even in strong CLIL programmes, the language subject was not substituted: the language teacher kept on providing linguistic support for those subjects that were not from a linguistic area but which were (partly) taught in the FL. In other words, "CLIL does not happen instead of FL teaching but alongside it" (Dalton-Puffer et al., 2014: 215), and "team teaching" (Fortanet-Gómez, 2013: 164) is thought to be the ideal situation in CLIL settings.

As mentioned above, the role of the CLIL teacher is vital for the correct development of any CLIL programme. That is precisely the reason why in both the APPP and the PEDLA teacher training surfaces as one of the key areas that need stepping up. As Coyle (2011; in Pérez Cañado \& Ráez Padilla, 2015: 7) put it, teacher training is "where CLIL will stand 
or fall in terms of sustainability". It has been suggested that training in CLIL contexts should be provided both to new lecturers (pre-service training) and to lecturers who are already part of the institution (in-service training), via language courses, testing schemes, and translation facilities, as in the case of teachers at the University of Delft (Vinke, 1995; Fortanet-Gómez, 2013), provided that the three dimensions of CLIL teacher training are English language proficiency, pedagogical aspects, and interculturality and multilingualism (Fortanet-Gómez, 2010).

The APPP stated that teacher training constituted "one of the pillars of any education system" (Junta de Andalucía, 2005: 42), and it intended to improve teaching quality through a series of programmes. The Teachers and Plurilingualism programme was dedicated to the improvement of teachers' working conditions. For that matter, Teacher Training Centres and other institutions work together in order to ensure that teachers are updated in their language skills, methodological practices, materials development and assessment criteria, and that they are able to implement the European Language Portfolio at all levels. Moreover, mobility is encouraged, and networks of Andalusian and other European schools are established via programmes such as Grundtvig and Comenius (Junta de Andalucía, 2005).

The bilingual schools programme, also embedded within the APPP, provided support for teachers through specific training, curriculum-related teaching materials and equipment, technological equipment, agreements with foreign institutions, language assistants, specialised language classrooms, cultural activities, and exchange visits, amongst others.

The Official Language Schools (OLS) programme was designed not only to teach FLs to students, but also to teachers from bilingual schools who wanted to improve their language skills in order to be able to teach their NLA subject through CLIL. These are the so-called "Cursos de Actualización Lingüistica" (Language Actualization Courses). In sum, the OLSs serve as a chief element of the APPP by supporting the structure of the bilingual schools programme via teacher training, language certification, outreach to the community, and language instruction (Junta de Andalucía, 2005).

The PEDLA also proposes some actions with regard to teacher training that will be carried out in joint efforts with universities, Teacher Training Centres, and Official Language Schools. Some of the key areas which will be boosted include linguistic upgrading to a $\mathrm{C} 1$ level on the part of teachers, methodological training (especially in relation to turning the CLIL class into a more participative, technology-friendly and student-centred one), the use of the European Language Portfolio, job shadowing, and attention to diversity.

\section{Methodology}

\subsection{Objectives}

The broad aim of this study is to carry out a large-scale longitudinal study evaluating CLIL from a qualitative standpoint in a firmly entrenched monolingual setting where students have little exposure to the English language outside the school setting. This study seeks to analyse the teachers' impressions on the APPP as well as their level of satisfaction generated by the APPP, and to determine the existence of intra-group differences in their perceptions. This in-depth analysis will allow us to paint a clearer picture of the way CLIL is imple- 
mented at the grassroots level in terms of methodology, materials, and evaluation. The main objective can be broken down into two key metaconcerns which serve as cornerstones for this evaluation and consultancy project, divided into several component corollaries:

Metaconcern 1 (Needs analysis)

1. To determine teachers' perceptions with regard to their L2 competence in CLIL classes at both Primary and Secondary education levels.

2. To determine teachers' perceptions of the methodology employed in CLIL at both Primary and Secondary education levels.

3. To determine teachers' perceptions of the materials and other resources that are employed in CLIL at both Primary and Secondary education levels.

4. To determine teachers' perceptions of the evaluation system in CLIL lessons at both Primary and Secondary education levels.

5. To determine teachers' satisfaction concerning the teacher-training actions required for successful CLIL teaching.

6. To determine teachers' perceptions with regard to mobility.

7. To determine teachers' perceptions of the coordination and organisation in CLIL classes at both Primary and Secondary education levels.

Metaconcern 2 (Within-cohort comparisons)

8. To determine whether, within the teacher cohort, there are any statistically significant differences in perception in terms of the identification variables considered (age, gender, administrative situation, English level, overall teaching experience, teaching experience in bilingual schools, and number of subjects taught in English).

\subsection{Research design}

This study constitutes an example of primary survey research, given that both interviews and questionnaires have been employed for its data gathering process (Brown, 2001). Four types of triangulation are employed, namely data, methodological, investigator, and location. This ensures the reliability and robustness of the data, since accounts of what CLIL entails have been provided by multiple sources.

i) Data triangulation, since three different stakeholders have taken part in this study: NLA teachers, English language teachers, and teaching assistants.

ii) Methodological triangulation, given that different data-gathering procedures have been employed, namely questionnaires and interviews. ${ }^{3}$

iii) Investigator triangulation, due to the fact that, across provinces, several investigators have participated in the data-gathering process, to then draw their personal conclusions concerning their findings.

iv) Location triangulation, since the questionnaires and interviews have been conducted in four Andalusian provinces: Almería, Córdoba, Granada, and Jaén. Moreover, both Primary and Secondary schools have participated in the study, thus multiplying the number of data-gathering sites.

\footnotetext{
${ }^{3}$ These questionnaires can be obtained from Pérez Cañado (2016c:94-100).
} 


\subsection{Sample}

For this study, a total of 101 teachers have participated from the four above-mentioned provinces (Almería, Córdoba, Granada, and Jaén). It must be noted that, compared with other types of cohorts (students and parents) employed in other studies, the teacher cohort is fairly more reduced, given the teacher-student ratio per classroom. Out of all informants for this study, the most representative cohort is that of NLA teachers $(64.6 \%)$, followed by English teachers $(30.3 \%)$, and by language assistants $(2 \%)$. The remaining $3 \%$ is comprised of teachers that consider themselves none of the above categories (cf. Graph 1). As far as gender is concerned, $39.6 \%$ are men, whereas $60.4 \%$ are women (cf. Graph 2).

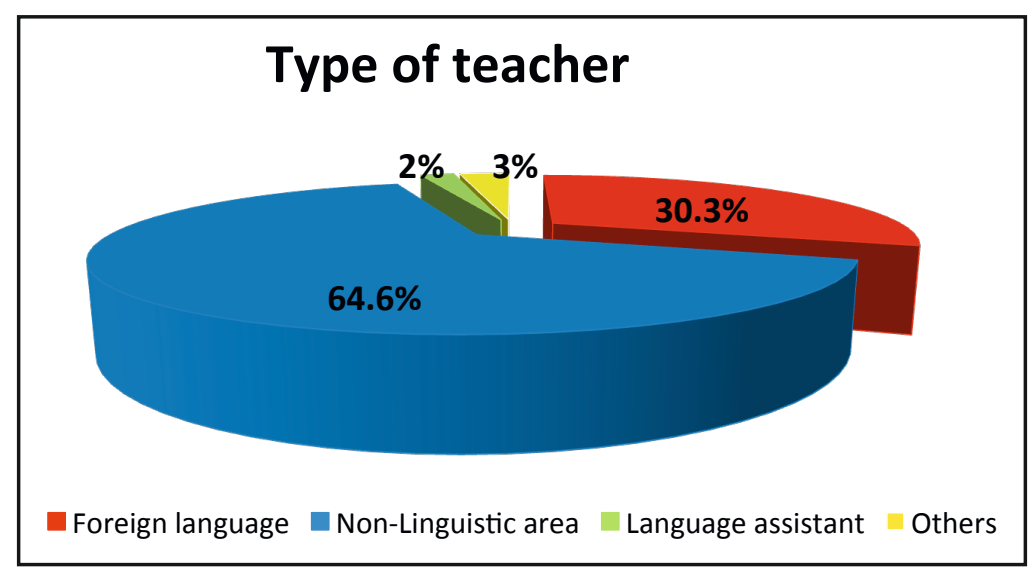

Graph 1. Breakdown of the overall sample in terms of cohort

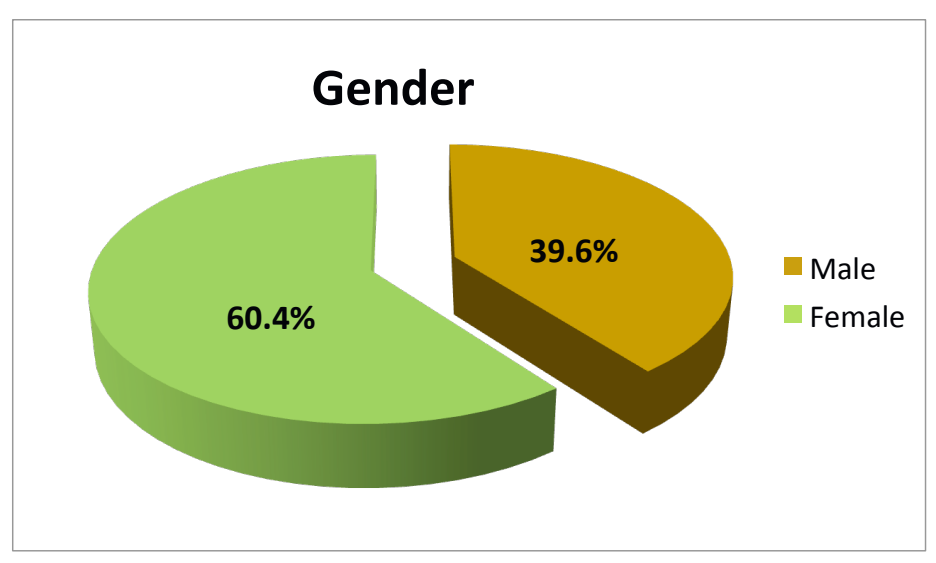

Graph 2. Breakdown of the overall sample in terms of gender 
The vast majority of teachers are of Spanish nationality (98\%). In addition, $1 \%$ are non-Spanish European, and the remaining 1\% are of non-European origin. With regard to their age, a slight majority are older than 40 years-old $(53.1 \%)$, and $46.9 \%$ are 40 or younger. Most of the teachers are civil servants who are teaching in their allocated destination $(68.3 \%) .4 \%$ have already passed their entry exams but have not yet received their definitive job destination, and $16.8 \%$ of teachers have yet to pass the exams to become a civil servant. $10 \%$ consider themselves to be in a different administrative situation from the above-mentioned ones. Furthermore, $13.8 \%$ are bilingual coordinators.

The majority of the practitioners have a B2 level in English (60.8\%), followed by $18.6 \%$ of teachers who have stated that they have a $\mathrm{C} 1$ and $12.4 \%$ who have acquired a $\mathrm{C} 2$ level in the FL. This leaves us with an $8.2 \%$ of practitioners who report having a B1 $(7.2 \%)$ or a lower level $(1 \%)$. Most teachers in our sample $(37.6 \%)$ have 1 to 10 years of teaching experience, followed by those (34.7\%) who have between 11 and 20 years of teaching experience, $19.8 \%$ who have been teaching for between 21 and 30 years, $5.9 \%$ who have more than 30 years of experience, and $2 \%$ who have been teaching for less than a year. The vast majority have been involved in bilingual education for either between 1 and 5 years $(52.5 \%)$ or between 6 and 10 years $(36.6 \%)$, which attests to the level of experience that Andalusian teachers have acquired with respect to bilingualism, in which they have been involved from the outset of the APPP programme.

\subsection{Variables}

A series of identification (subject) variables have been considered, which are adapted to fit the individual features of each of the three different stakeholders who take part in the investigation: NLA teachers, English teachers, and language assistants. The variables examined for the teacher cohort are enumerated below:

- Type of school

- Age

- Gender

- Nationality

- Type of teacher

- Administrative situation

- Level of English

- Subjects taught in English

- Overall teaching experience

- Teaching experience in a bilingual school.

\subsection{Instruments}

For this study, two main data-gathering tools have been employed: questionnaires (both self- and group-administered) and interviews. The questionnaires, which have been validated in Spanish and in English, included both demographic or background questions (that served the purpose of gathering basic biographical data from the teachers) and opinion questions (that gathered the respondents' views with regard to the APPP programme in the four Andalusian provinces). Therefore, the stakeholders' views have been gathered using survey tools 
(Brown, 2001). The two kinds of questions (background and opinion questions), in turn, are in line with Patton's (1987) question types.

For the development of these questionnaires, a double-fold pilot procedure has taken place. Both a group of experts and a representative sample of informants in a pilot phase have provided their feedback on them, which has been taken into consideration for their final versions. In order to guarantee questionnaire reliability, Cronbach alpha was calculated, which was extremely high for the teacher questionnaire with a 0.931 . As for the group interviews, semi-structured interview protocols were employed, and the researchers in the four provinces where this study takes place were provided clear-cut questions to be answered by the teachers as well as training on common guidelines and directions to offer to the interviewees. The interview questions, although predetermined, left some space for the teachers to expand on those areas that they believed needed more elaboration. The interviews were held in each school, lasted roughly one hour each, and they were digitalised, with prior consent from the participants.

\subsection{Data analysis: statistical methodology}

The data collected have been statistically analysed by means of the SPSS programme, version 21.0. For Metaconcern 1 (needs analysis, objectives 1-7), descriptive statistics have been used. Therefore, both central tendency (mean, median, and mode) and dispersion measures (range, low-high, and standard deviation) have been calculated. In turn, for Metaconcern 2 (within-cohort comparisons, objective 8) several statistical tests have been employed; namely the ANOVA, t-test, and Mann-Whitney $U$ test, with the aim of finding statistically significant differences within groups, bearing in mind the identification variables considered in the study. For the semi-structured interviews, Grounded Theory analysis (Glaser \& Strauss, 1967) has served as the framework of reference for data coding, memoing, and drawing of conclusions, with the objective of categorising, synthesising, and identifying emerging patterns in the open-response data.

\section{RESUlts AND DisCUSSION}

Regarding the first Metaconcern 1 (objectives 1-7), this study has allowed us to analyse the teachers' perspectives on CLIL implementation vis-à-vis the above-mentioned ten main fields of interest: L2 use in class, L2 development: discursive functions, and competence development (block 1), methodology (block 2), materials and resources (block 3), evaluation (block 4), teacher training and motivation (block 5), mobility (block 6), and coordination, organization, workload, and overall appraisal of bilingual programs (block 7).

First of all, it should be mentioned that, bearing in mind the use of a 1 to 4 Likert scale (1 meaning "Totally disagree", and 4, "Totally agree"), the average marks in most cases is above 3 . Such is the case in 41 out of 61 items, which shows positive results, generally speaking.

With regard to the teachers' perceptions concerning their students' L2 competence in CLIL classes at both Primary and Secondary education levels, the results show that in most cases (9 out of 14 ) they have a positive impression. They think that both their students' L1 
and L2 as well as their knowledge of the contents of the subjects taught in English have improved as a consequence of CLIL implementation. They also consider that their students are now more self-confident and willing to participate, and more aware of the connections between L1 and L2, which are some of the most commonly considered positive aspects of CLIL programmes (Marsh, 2000; Coyle, 2006; Merisuo-Storm, 2007; Seikkula-Leino, 2007; Marsh, 2008²; Lorenzo, Casal \& Moore, 2009; Lasagabaster, 2011; García Sánchez \& Rodríguez Collado, 2015; Heras \& Lasagabaster, 2015; Lancaster, 2015; Lancaster, 2016). Teachers' perceptions are slightly less positive (between 2.59 and 2.95) when asked about their students' adequate capacity in L2 oral and written skills, together with socio-cultural aspects. The item with the lowest average (2.59) has to do with the students' willingness to have the number of hours taught in English increased. In the first block, the item with the highest average (3.52) can be found since teachers agree on the fact that their students' English has improved as a consequence of taking part in the bilingual programme. These results are in line with those obtained by Lancaster (2015) on teachers' perception of student improvement in the L2, which show that, according to teachers, following a CLIL programme has a positive effect on the students' level of English.

Vis-à-vis their perceptions of the methodology employed in CLIL, they are quite positive since all of them except for one have an average above 3. Thus, teachers think that different methodologies such as task-based learning, project-based learning, and cooperative learning are used in class. Moreover, the connections between L1 and L2 are underlined and the guidelines of both the Common European Framework of Reference for Languages (henceforth CEFRL) and the European Language Portfolio are followed. The only item below 3 has to do with the fact that teachers do not agree so much on the fact that the lexical dimension is given more prominence in class, which contrasts with Lancaster's (2015) study, who found that teachers believed students had improved their competence in the L2 only in a lexical sense and that, later in time, it was difficult for them to retain the information learned.

Moreover, their impressions concerning the materials and other resources that are employed in CLIL are quite positive since two thirds of these items are highly valued by teachers. They consider that both authentic and adapted materials are used in class, that CLIL materials are interesting and foster communication, and that CLIL teachers collaborate to prepare and teach CLIL materials, although they are not adapted to cater for the needs of all students. However, they have mixed feelings when providing their opinion concerning ICT. Thus, they quite agree on the use of some resources such as multimedia, online references, and digital boards, but such is not the case of blogs, wikis, webquests, and computer-mediated communication, with slightly lower results. ICTs have been considered in other studies one of the strengths of the CLIL programme in Andalusia (Cabezas Cabello, 2010), and teachers have reported to be competent in the use of these technologies, contrasting sometimes with the students' perceptions (Lancaster, 2016). The lowest average (2.27) is given to whether CLIL materials include some guidelines in Spanish so that parents can help their children at home. This thus comes across as one of the key areas for future improvement, in line with the findings of previous studies (Cabezas Cabello, 2010; Pérez Cañado, 2011; Gálvez Gómez, 2013; Lancaster, 2015). 
In addition, the teachers' perceptions of the evaluation system in CLIL lessons are quite positive since 3 out of 4 items show an average over 3 . Thus, teachers consider that all contents are assessed, contents are prioritised over linguistic aspects, and evaluation is diverse, formative, summative, and holistic. Still, the item with the lowest average (2.97), as expected, is connected with the fact that oral components are also taken into account for evaluation. This pitfall coincides with Lancaster (2016: 160), who reported that, although teachers "are satisfied with the way evaluation is dealt with, [...] they also admit an oral component is not always incorporated into assessment". Traditionally, in the Spanish educational system, oral skills are usually neglected in the learning-teaching processes. This situation has gradually improved in the last decades, but written skills are still awarded primacy by teachers in their everyday practice.

Furthermore, their satisfaction concerning the teacher training actions required for successful CLIL teaching is relative. On the one hand, they consider that the three cohorts (L2 and NLA teachers as well as FL assistants) require more training and the items with lower averages have to do with their taking part in CLIL training (2.91) and Language Actualization Courses (2.85). On the other, however, they state that all the types of teachers motivate students and that FL assistants usually collaborate successfully with both students and teachers (as previously concluded by Tobin and Abello Contesse, 2013, and by Sánchez Torres, 2014). In fact, they highlight the fact that they have the appropriate oral and written skills, and are familiar with the socio-cultural aspects of the L2 together with the APPP and CLIL.

With regard to mobility, this is the block in which their perceptions are lower, including the item with the lowest score too (1.71; cf. Graph 3). Here, teachers acknowledge that they do not often take part in exchange programmes, or linguistic and methodology courses abroad. They do not usually obtain study or research leaves either. Lancaster (2016) reported similar outcomes with regard to mobility and training abroad, although participation in exchange programmes had increased amongst teachers due to their participation in CLIL. Nevertheless, these findings contrast with teachers' calls for further training in both theoretical and linguistic aspects, which are one of the main weaknesses identified in the literature (Navés, 2009; Rubio Mostacero, 2009; Cabezas Cabello, 2010; Pérez Cañado, 2012; Gálvez Gómez, 2013; Pérez Cañado, 2013; De la Maya Retamar \& Luengo González, 2015; Pérez Cañado, 2015; Pérez Cañado and Ráez Padilla, 2015; Pérez Cañado, 2016b). Teachers, therefore, are "visibly not taking advantage of these initiatives" (Lancaster, 2016: 161).

As for the teachers' perceptions of the coordination and organisation in CLIL classes, they think that not only they but also coordinators perform their functions within the APPP, and that their communication with their coordinators is smooth. The results are slightly lower concerning their collaboration in the Integrated Language Curriculum (2.93) and the support they think they receive from educational authorities (2.15).

Finally, their overall appraisal of bilingual programs is positive: in spite of the fact that their workload has increased, they consider it is worth the effort. 


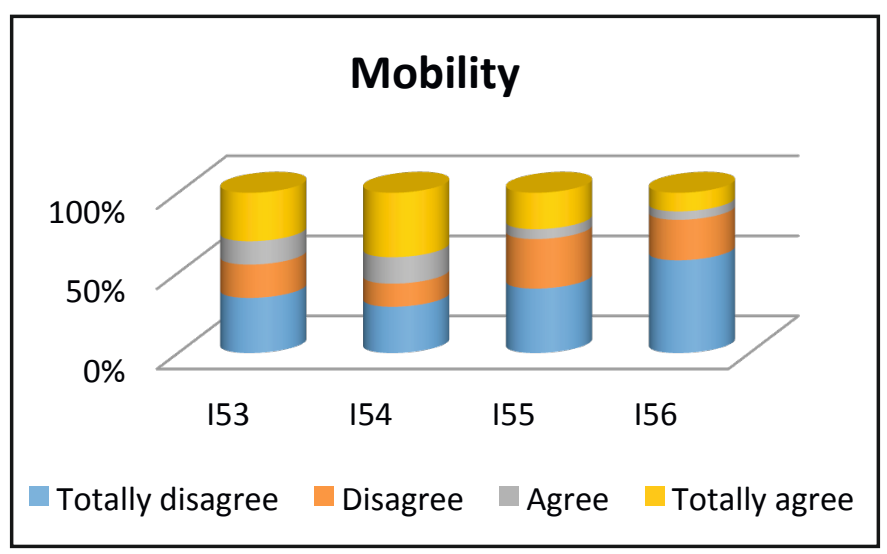

Graph 3. Global results concerning mobility

Turning now to Metaconcern 2 (objective 8), statistically significant differences can be detected in terms of the above-mentioned identification variables. They have been found in every single variable, but the one with the highest number is type of teacher (34 out of 61 items). Quite on the contrary, other variables such as age, overall teaching experience, teaching experience in bilingual schools, administrative situation, gender, and the number of subjects taught in English present statistically significant differences in just 15 or fewer items $(1,4,6,8,10$, and 15 , respectively).

The different types of teachers have been classified into two groups (NLA teachers and FL teachers) and the block with the highest number of differences is the first one (cf. Graph 4). In this respect, they have been identified in 12 out of the 14 items, their perceptions being closer only regarding their students' improvement of the L1 and their interest in bilingual classes. In the rest of cases, FL teachers always have a more positive perception of their students' L2 use in class and L2 competence development than NLA teachers. This is due to the fact that in their classes L2 teachers usually focus on linguistic competence, whereas NLA teachers pay more attention (and may give more prominence, too) to the contents being covered. Lancaster (2012) also found that FL teachers revealed more positive attitudes than NLA teachers towards items that fall under their domain. Nevertheless, when questioned about listening and speaking skills in the L2, both FL and NLA teachers are positive about the students' competences in English. 


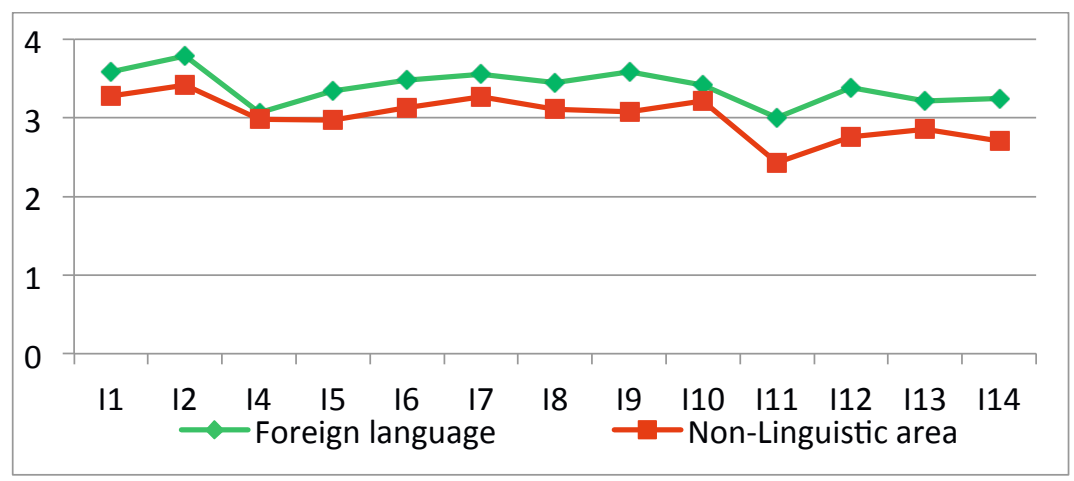

Graph 4. Students' L2 use, competence and development according to the type of teacher

In turn, their perceptions regarding methodology, mobility, and coordination and organization are quite similar, but such is not the case of the other blocks. FL teachers always have a more positive impression regarding CLIL materials (interesting, innovative, and adapted to their students' needs) and the evaluation of oral skills and assessment (which is not only continuous but also summative). With regard to teacher training, FL teachers also perceive the FL assistants' performance as more motivating and their attitude as more collaborative. This could be explained by the fact that, due to their position in the school and their previous experience as language educators, FL teachers have a clearer idea of the Language Assistant's role in class, which in turn creates a better relationship between them and fosters coordination and cooperation. In Tobin and Abello Contesse's (2013) study, it was inexperienced teachers who failed to capitalise on the benefits that language assistants could bring to their class, and, in those cases in which the language assistant's role had been clarified, the results were more positive. In addition, FL teachers also think that their oral and written skills as well as their knowledge of socio-cultural aspects, the APPP, and CLIL are adequate, whereas NLA teachers always show lower averages concerning all these issues.

Curiously enough, the only item in which the NLA teachers' average is significantly higher than FL teachers is related to a specific item within evaluation, since they consider that contents are given more prominence than linguistic accuracy in exams, as well as in both oral presentations and written assignments.

The variable with the second higher number of statistically significant differences is the teachers' English level. A distinction has been drawn between, on the one hand, A1, $\mathrm{A} 2, \mathrm{~B} 1$, and $\mathrm{B} 2$, and, on the other, $\mathrm{C} 1$ and $\mathrm{C} 2$. The latter have higher averages than the former in most items (56/61). As in the case of the previous variable, the first block is the section comprising the highest number of differences. More proficient teachers think that their students' L2 use in class and L2 competence development is better than less proficient ones. With regard to teacher training, this block includes 2 of the 5 exceptions, that is to say, items in which less proficient teachers show higher averages than more proficient ones; such is the case of both FL and NLA teachers requiring more training. As Pérez Cañado (2016a) explains, this trend could be explained by the B2 requirement to participate in the CLIL scheme: less proficient teachers feel that they need to upgrade their linguistic competence in 
order to continue being part of the bilingual programme, and, therefore, they express their desire for further training.

Finally, bilingual coordinators show higher averages in all the items except for 5 and there are statistically significant differences in 26 items. Most of them are found in the first block and, more outstandingly, in blocks 5 (teacher training), 6 (mobility), and 7 (coordination and organization). It must be underlined that the greatest differences between both cohorts can be found regarding mobility, since the coordinators' averages prove higher than the rest of teachers' in the rest of blocks, particularly in the case of language and methodology courses abroad.

\section{Conclusion}

This article has tackled a crucial issue nowadays. After the implementation of the APPP and at the very beginning of the brand new PEDLA, we considered it necessary to look back and check what teachers think about CLIL considering different variables. All the stakeholders involved in CLIL play a key role and their opinions should also be taken into account. In fact, the research projects mentioned in the acknowledgements have also taken students' and parents' viewpoints into account, but they fall beyond the scope of this paper (cf. Oxbrow and Ráez Padilla's contributions in this volume for the results affecting these other two cohorts).

With regard to Metaconcern 1, most teachers have a positive impression about their students' L2 competence in CLIL classes; they think that a wide range of different methodologies, materials and resources are used in class (although some examples of ICT are not widely employed yet); that many diverse aspects are taken into account for evaluation (even though oral issues are still somehow neglected); and that more teacher training is required. In line with this, although there are more and more academic events such as courses, seminars, and workshops, among others, that are organized by different institutions, they do not seem to satisfy the teachers' needs yet. In addition, teachers will soon benefit from other training possibilities as Master's programmes especially designed to meet their demands. Finally, they admit they should improve different aspects concerning mobility and consider that, in spite of the increase in their workload, it is definitely worth the effort.

As for Metaconcern 2, the main statistically significant differences have been found in three out of 11 identification variables: type of teacher, the teachers' English level, and bilingual coordinators. Generally speaking, FL teachers, teachers who are more proficient in English (with a $\mathrm{C} 1$ or $\mathrm{C} 2$ level), and coordinators tend to value most items more highly than NLA teachers, less proficient teachers (from A1 to B2), and teachers who are not coordinators, respectively.

The outcomes of all the analyses carried out within the framework of both projects will be at the disposal of the educational authorities so that they can study them in depth and be in a better position to take the right decisions concerning all the CLIL stakeholders in the short, medium, and long term. 


\section{REFERENCES}

Blanca Pérez, A. (2009). "Contribución a la mesa redonda 'La administración educativa en la organización de la enseñanza plurilingüe"”, in A. Bueno González, J. M. Nieto García and D. Cobo López (eds.) Atención a la diversidad en la enseñanza plurilingüe. I, II y III Jornadas Regionales de Formación del Profesorado (CD- ROM). Jaén: Delegación Provincial de Educación de Jaén y Universidad de Jaén.

Bowler, B. (2007). "The rise and rise of CLIL", in New Standpoints, Sep-Oct 2007: 7-9.

Brown, J. D. (2001). Using surveys in language programs. Cambridge: Cambridge University Press. Bruton, A. (2013). "CLIL: Some of the reasons why... and why not", in System, 41: 587-97.

Cabezas Cabello, J. M. (2010). "A SWOT analysis of the Andalusian Plurilingualism Promotion Plan (APPP)", in M. L. Pérez Cañado (ed.), Proceedings of the 23rd GRETA Convention. Jaén: Joxman, 83-91.

Casal, S. and Moore, P. (2008). "The Andalusian bilingual sections scheme: Evaluation and consultancy", in International CLIL Research Journal, 1, 1: 36-46.

Council of Europe (2001). Common European framework of reference for languages: Learning, teaching, assessment. Cambridge: Cambridge University Press.

Coyle, D. (2006). "Content and language integrated learning: motivating learners and teachers", in Scottish Languages Review, 13: 1-18.

Coyle, D. (2011). "Setting the CLIL agenda for successful learning: What pupils have to say" (plenary conference at the II Congreso Internacional de Enseñanza Bilingüe en Centros Educativos). Madrid: Universidad Rey Juan Carlos.

Dallinger, S., Jonkmann, K., Hollm, J. and Fiege, C. (2016). "The effect of content and language integrated learning on students' English and history competences. Killing two birds with one stone?", in Learning and Instruction, 41: 23-31.

Dalton-Puffer, C., Llinares, A., Lorenzo, F. and Nikula, T. (2014). "You can stand under my umbrella. Immersion, CLIL and Bilingual Education. A response to Cenoz, Genesee \& Gorter (2013)", in Applied Linguistics, 35, 2: 213-18.

De la Maya Retamar, G. and Luengo González, R. (2015). "Teacher training programs and development of plurilingual competence", in D. Marsh, M. L. Pérez Cañado and J. Ráez Padilla (eds.). Newcastle-upon-Tyne: Cambridge Scholars Publishing, 114-129.

Deller, S. (2005). "Teaching other subjects in English (CLIL)", in In English!, Spring 2005: 29-31.

Europa Press (2014). "Andalucía contará con 915 centros docentes públicos bilingües el próximo curso". Available from http://www.europapress.es/andalucia/sevilla-00357/noticia-comunidad- autonoma-andaluza-contara-proximo-curso-915-centros-docentes-publicos-bilingues$20140318152612 . h t m l$, accessed 18 May, 2017.

Europa Press (2017). “Andalucía extenderá hasta Secundaria el aprendizaje obligatorio de dos idiomas". Available from http://www.europapress.es/esandalucia/sevilla/noticia-juntaaprueba- plan-incrementar-implantacion-bilinguismo-2020-20170123182919.html, accessed 18 May, 2017.

European Commission (1995). White paper on education and training. Teaching and learning. Towards the learning society. Brussels: European Commission.

European Commission, Directorate-General for Education and Culture, Vocational Training \& Language Policy. (2005). Europeans andlLanguages: A Euro-barometer special survey. $B$-1049. Brussels: European Commission.

Eurydice (2006). Content and Language Integrated Learning (CLIL) at school in Europe. Brussels: Eurydice. 
Fortanet-Gómez, I. (2010). "Training CLIL teachers at university level.”, in D. Lasagabaster and Y. Ruiz de Zarobe (eds.), CLIL in Spain: Implementation, results and teacher training. Newcastle upon Tyne: Cambridge Scholars Publishing, 257-276.

Fortanet-Gómez, I. (2013). CLIL in higher education. Towards a multilingual language policy. Bristol: Multilingual Matters.

Gálvez Gómez, M. M. (2013). A SWOT analysis of CLIL implementation: A Case study in the province of Jaén (Unpublished master's thesis). Jaén: Universidad de Jaén.

García Mayo, M. P. (2009). "El uso de tareas y la atención a la forma del lenguaje en el aula de AICLE", in V. Pavón Vázquez and J. Ávila López (eds.), Aplicaciones didácticas para la enseñanza integrada de lengua y contenidos. Córdoba: Junta de Andalucía, Universidad de Córdoba and CETA, 55-74.

García Sánchez, M. E. and Rodríguez Collado, M. M. (2015). "The impact of competence-based education on bilingual programs in Andalusian secondary schools", in D. Marsh, Pérez Cañado and Ráez Padilla (eds.), CLIL in action: Voices from the classroom. Newcastleupon-Tyne: Cambridge Scholars Publishing.130-149.

Gierlinger, E. (2015). "'You can speak German, sir': On the complexity of teachers' L1 use in CLIL", in Language and Education, 29, 4: 347-68.

Glaser, B. and Strauss, A. (1967). The discovery of grounded theory: Strategies for qualitative research. Chicago: Aldine.

Heras, A. and Lasagabaster, D. (2015). "The impact of CLIL on affective factors and vocabulary learning”, in Language Teaching Research, 19: 70-88.

Junta de Andalucía (2005). Plan de Fomento del Plurilingüismo en Andalucía. Sevilla: Junta de Andalucía.

Junta de Andalucía (2017). Plan Estratégico de Desarrollo de las Lenguas en Andalucía. Available from: http://www.juntadeandalucia.es/educacion/webportal/abaco-portlet/content/462f16e3c047-479f-a753-1030bf16f822, accessed 18 May, 2017.

Lancaster, N. K. (2012). Stakeholder perspectives on CLIL development in a monolingual context: The case of Jaén (Unpublished master's thesis). Jaén: Universidad de Jaén.

Lancaster, N.K. (2015). The effects of Content and Language Integrated Learning on the oral skills of Compulsory Secondary Education students: A longitudinal study. (Unpublished doctoral thesis). Jaén: Universidad de Jaén.

Lancaster, N. K. (2016). "Stakeholder perspectives on CLIL in a monolingual context", in English Language Teaching, 9, 2: 148-177.

Lasagabaster, D. (2011). "English achievement and student motivation in CLIL and EFL settings", in Innovation in Language Learning and Teaching, 5: 3-18.

Lasagabaster, D. and Ruiz de Zarobe, Y. (2010b). "Ways forward in CLIL: Provision issues and future planning", in D. Lasagabaster and Y. Ruiz de Zarobe (eds.), CLIL in Spain: Implementation, results and teacher training. Newcastle upon Tyne: Cambridge Scholars Publishing, 278-95.

Llinares, A. and Dafouz, E. (2010). "Content and language integrated language programmes in the Madrid region: Overview and research findings", in D. Lasagabaster and Y. Ruiz de Zarobe (eds.), CLIL in Spain: Implementation, results and teacher training. Newcastle upon Tyne: Cambridge Scholars Publishing, 95-114.

Lorenzo, F. (2007). "The sociolinguistics of CLIL: Language planning and language change in 21st century Europe", in RESLA, 1: 27-38.

Lorenzo, F., Casal, S. and Moore, P. (2009). "The effects of Content and Language Integrated Learning in European education: Key findings from the Andalusian bilingual sections evaluation project", in Applied Linguistics, 31, 3: 418-42. 
Lorenzo, F., Casal, S., Moore, P. and Afonso, Y. M. (2009). Bilingüismo y educación. Situación de la red de centros bilingües en Andalucía. Sevilla: Fundación Centro de Estudios Andaluces.

Marsh, D. (2000). Using languages to learn and learning to use languages. Jyväskylä: University of Jyväskylä.

Marsh, D. (ed.) (2002). CLIL/EMILE. The European dimension. Actions, trends, and foresight potential. Jyväskylä: University of Jyväskylä.

Marsh, D. (20082). "Language awareness and CLIL", in N. Hornberger (ed.) Encyclopedia of Language and Education. New York: Springer, 1986-99.

Marsh, D. (2012). Content and Language Integrated Learning. A development trajectory. Córdoba: Servicio de Publicaciones de la Universidad de Córdoba.

Massler, U., Stotz, D. and Queisser, C. (2014). "Assessment instruments for primary CLIL: The conceptualisation and evaluation of test tasks", in The Language Learning Journal, 42: $137-50$.

Merisuo-Storm, T. (2007). "Pupils' attitudes towards foreign language learning and the development of literacy skills in bilingual education", in Teaching Teacher Education, 23: 226-35.

Ministerio de Educación, Cultura y Deporte (2012). Estudio europeo de competencia lingüistica EECL: Informe español. Madrid: Secretaría General Técnica. Available from: http:// www.mecd.gob.es/dctm/ievaluacion/internacional/eeclvolumeni.pdf?documentId=0901e72b813ac515, accessed 18 May, 2017.

Navés, T. (2009). "Effective Content and Language Integrated Learning (CLIL) programmes", in Y. Ruiz de Zarobe and R. Jiménez Catalán (eds.) Content and Language Integrated learning: Evidence from research in Europe. Bristol: Multilingual Matters, 22-40.

Oxbrow, G. L. (2018). "Students' perspectives on CLIL programme development: A quantitative analysis", in Porta Linguarum 29, 137-158.

Patton, M. Q. (1987). How to use qualitative methods in evaluation. London: Sage.

Pavón, V. and Ellison, M. (2013). "Examining teacher roles and competences in Content and Language Integrated Learning (CLIL)", in Linguarum Arena, 4: 65-78.

Pérez Cañado, M. L. (2011). "The effects of CLIL within the APPP: Lessons learned and ways forward", in R. Crespo Jiménez and Á. García de Sola (eds.) ESP teaching and methodology English studies in honour of Ángeles Linde López. Granada: Editorial Universidad de Granada, 389-406.

Pérez Cañado, M. L. (2012). "CLIL research in Europe: Past, present, and future", in InternationalJournal of Bilingual Education and Bilingualism, 15, 3: 315-41.

Pérez Cañado, M. L. (2013). "Introduction", in Revista de Lenguas para Fines Especificos, 19: $12-27$.

Pérez Cañado, M. L. (2015). "Training teachers for plurilingual education: A Spanish case study", in D. Marsh, Pérez Cañado and Ráez Padilla (eds.), CLIL in action: Voices from the classroom. Newcastle-upon-Tyne: Cambridge Scholars Publishing,14-30.

Pérez Cañado, M. L. (2016a). "Are teachers ready for CLIL? Evidence from a European study", in European Journal of Teacher Education, 39, 2: 202-21.

Pérez Cañado, M. L. (2016b). "Teacher training needs for bilingual education: In-service teacher perceptions", in International Journal of Bilingual Education and Bilingualism, 19, 3: 266-95.

Pérez Cañado, M. L. (2016c). "Evaluating CLIL programmes: Instrument design and validation", in Pulso. Revista de Educación, 39: 79-112.

Pérez Cañado, M. L. In press. "CLIL and pedagogical innovation: Fact or fiction?", in International Journal of Applied Linguistics. 
Pérez Cañado, M. L. and Ráez Padilla, J. (2015). "Introduction and overview”, in D. Marsh, Pérez Cañado and Ráez Padilla (eds.), CLIL in action: Voices from the classroom. Newcastleupon-Tyne: Cambridge Scholars Publishing, 1-13.

Pérez Vidal, C. (2013). "Perspectives and lessons from the challenge of CLIL experiences", in C. Abello-Contesse, P. M. Chandler, M. D. López-Jiménez and R. Chacón-Beltrán (eds.), Bilingual and multilingual education in the 21st century. Building on experience. Bristol: Multilingual Matters, 59-82.

Ráez Padilla, J. (2018). "Parent perspectives on CLIL implementation: Which variables make a difference?", in Porta Linguarum 29: 181-196.

Rubio Mostacero, M. D. (2009). Language and teacher training for non-language teachers: Meeting the needs of Andalusian teachers for school plurilingualism projects. Design of a targeted training course. Jaén: Universidad de Jaén.

Sánchez Torres, J. (2014). Los papeles que desempeñan el 'auxiliar de conversación' y el 'profesor- coordinador' en centros bilingües Español/Inglés de Sevilla. Un estudio empírico de casos (Unpublished doctoral dissertation). Sevilla: Universidad de Sevilla.

Seikkula-Leino, J. (2007). "CLIL learning: Achievement levels and affective factors", in Language and Education, 21: 328-41.

Tobin, N. A. and Abello-Contesse, C. (2013). "The use of native assistants as language and cultural resources in Andalusia's bilingual schools", in C. Abello-Contesse, P. M. Chandler, M. D. López-Jiménez and R. Chacón-Beltrán (eds.), Bilingual and multilingual education in the 21st century. Building on experience. Bristol: Multilingual Matters, 203-30.

Vinke, A. A. (1995). English as the medium of instruction in Dutch-engineering education (Doctoral thesis). Delft, Netherlands: Delft University Press. Retrieved from https://repository. tudelft.nl/islandora/object/uuid:491b55f9-fbf9-4650-a44d-acb9af8412a8/ datastream/OBJ, accessed 29 September, 2017.

\section{ACKNowledgements}

This paper reports on some of the outcomes of the R\&D projects FFI2012-32221 and P12-HUM-2348, funded by the Ministerio de Economia y Competitividad and the Junta de Andalucia, respectively. 